$=2$

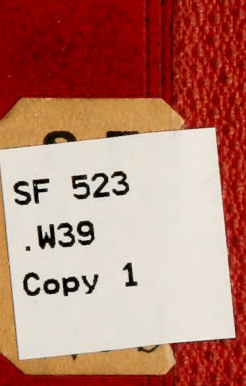

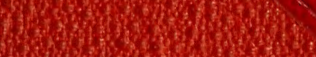

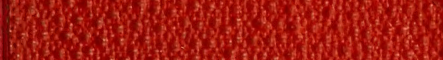

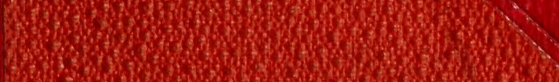

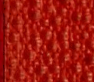

13.5.

W. (6)

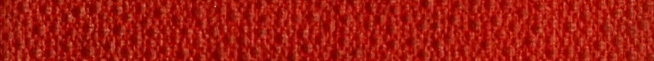
H 3 3 s. Q46.0.

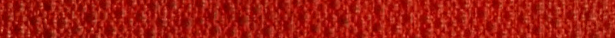
170

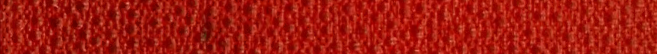

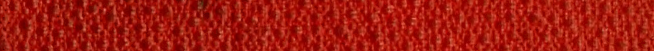
Lof 2.3.

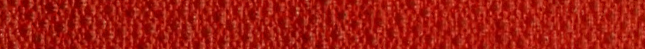

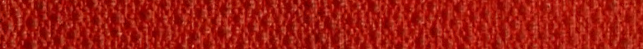

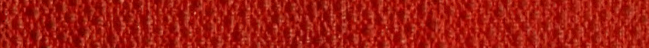

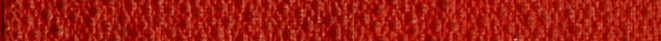

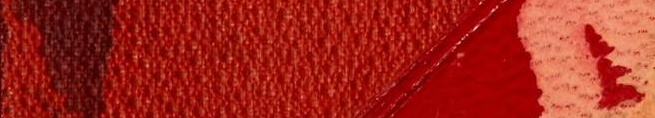


LIBRARY OF CONGRESS.

Cfrit. $8 \mp 523$

$$
\text { shelf. N39 }
$$

UNITED STATES OF AMERICA. 




Distical Cadei Ofinie? Trament Sarbic, twix."

one $2.15360 \quad\}$

This cojey deporitase

on thin stow Iy hin

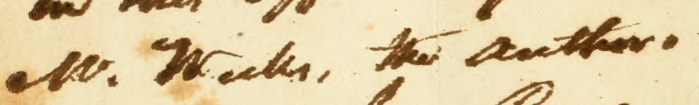

Hela Cove, clested the sistiak.

Ree cr Depr Tiet.21

$1837-$

$$
4-5-52
$$


w.. $\quad \mathbb{A} \mathbb{N} \cup \mathbb{A}$ :

OR AN

E A S Y METHOD

\title{
MANAGING BEES,
}

\author{
IN THE MOST
}

PROFITABLE MANNER TO THEIR OWNER,

\section{W ITH}

INFALLIBLE RULES TO PREVENT THEIR DESTRUCPION BY THE MOTH.

MIDDLE. BUR Y :

BNAPP A A JEWETT, PRINTERB.

1836. 


$$
\begin{aligned}
& \text { SF } 523 \\
& W 39
\end{aligned}
$$

Entered according to act of Congress, in the year 1836 , By JoHn M. WeEKS,

In the Clerk's Office of the District Court of Vermont

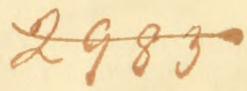




\section{PRE A C E .}

It appears to the writer of the following pages, that a work uf this description is much needed in our commery.

The cultivation of the iee (Apis Mrlifica) has been too fong neglected in most parts of the Umted Siates.

This geateral ne lact, that th: Europt an en. my to the bees, called th moth, has found its way into this cometry, an thas lacated and na turalized itself here: and has male sim inch havoc among the hees, that many districts have entre!y ahandoned their culivation. Many Aprarians, am? men of the hughest liferaty anamments, as well as experience, have neaty exhusted their paticuce, in examining the peculiar nature and hathis of this inseet: and have tried varions experiments, to devise some neans of preventing its depredations. Dut, atter all that has been clon', the sproiler muves onward with as litle molestation. That but rery few of our citizens are willing to eneage in tise cnterprize of cutit. valing this turst useful and profitable of all insects, the honeybee.

The following wo:k is enmprised in a set of p'ain, concise, rules, toy whicen, if strietly a thered to and practiced, any person, preperly ituachl, mo chitivite bees, and avai! homself of ali the benefits of their labors.

If the Aprart n mantges strictly in accordance with the forlowing sules, the Author fote is contident, that no colony will ever materatly suffir by the muth, or will ever be destroyed by them.

The author is aware of the numernas treatises published on this subject; but they appear to aim, for the most part, not to be the reanli of so much experience as vague and conjectural speculation, and not sutfictently embodying what is practical and useful.

This work is infen:led as an accompaninzent to the Vermont hive, and will be finum to be the resuli of observation and experience, and it is thmught comprises all that is necessary to make a skilful Apiarian.

THE AUTHOR. 


\section{N D EX.}

RULE I. On the construction of the hive, -
RULE II. On swarming and hiving, -
RULE 111. On ventilating, -

For.: Fr11. On suyplying swarms wih Q Zueens, when necessary,

Rutx IX. On nulliplying colonies to any desirable extent, without swarming, - - - - 41

Reis: X On preventing the deprutations of the moth, Rus $\Sigma$ X1. On feeding, - - - - - - 5 Russ XII. On wintering, - - - - - - 6

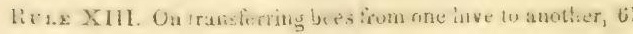
XIV. Genera! observations, - - - - 6 


\section{MA N U A L, \&O.}

\section{RULE I.}

TN THE CONSTRUCTION OF A BEE HIVE.

A beehive should be made of sound boards: free from shakes and cracks; it should also be planed smooth, inside and out, made in a workmanlike manner, and painted on its nutsidde.

\section{R E M A R K S .}

That a beehive should be made perfect, so as to exclude light and air, is obvious from the fact, that the bees will finish what the workman has neglected, by plastering up all such cracks and crevices, or bad joints, which are left open by the joiner; this substance is neither honey nor wax, but a kind of glue or cement of their own manufacturing, and is used by the bees to fill up all imperfect joints and exclude all light and air. This cement 
or grlue is very congenial to the growth of the moth in the first stages of its existence.

The moth miller enters the hive, generally, in the night, makes an incision into the glue or cement with her abdominal sting, leaves her ergs deposited in the glue, where it remains secure from the bees; it being guarded by the timber on its sides. Thus, while a magrot, (larva) the moth uses the cement for food until it arrives so far towards a state of maturity as to be able to spin a web, which is move fully explained in our remarks on Rule 10.

The size of a hive should be in accordance with the strictest rules of economy, and adapted to the peculiar nature and economy of the loney-bee, in order to make them profitable to their owner.

The lower apartment of the hive, where they store their food, raise their young bees, and perform their ordinary labors, should hold as much as a box thirteen inches and one half or fourteen inches square in the clear or area. If the hive is much larger than the one de- 
scribed above, with their chamber in proportion, which should hold aluout two thirds as much as the lower apartment, the bees will not be likely to swarm during the season.

Large hives never swarm; and those, much less than the one already described, do but little else than raise young bees and lay up a sufficient quantity of food to supply them through the coming winter, and are more liable to be robbed.

All hives that swarm are liable to swarm too much, and reduce their colonies so low in numbers as to materially injure them, and is frequently the cause of their destruction by the moth, which is more particularly explained in our remarks on Rule 2.

The chamber of the hive should be made perfectly tight, so as to exclude all light from the drawers.

Drawers should be small like No. 2, for all purposes except such as are used for multiplying colonies and transferring, which should always be large like No. 1 .

Hives should have cleets on their sides, so 2* 
as to suspend them in the air some distance from the floor of the apiary, the better to secure the bees from destruction by mice, reptiles, and other vermin.

The back side or rear of the lower apartment of the hive should project or slant forward, so as to render the same smallest at the bottom, the better to secure the combs from falling when cracked by frost or nearly melted in hot weather.

No timbers or boards should come very near the lower edge of the hive, because it facilitates the entrance of depredators. That the back side should slant forward, is obvious from the fact, that bees generally rest one edge of their combs on the same and build towards the front in such a manner as to enter upon the same sheet where they intend to deposit their stores, where they first enter the hive, without being compelled to take any unnecessary steps.

The bottom of the hive should slant downward from rear to front, so as to afford the greatest facility to the bees to clear their ten- 
ement of all offensive substances, and let the water, which is occasioned by the breath and steam of the bees, run off in cold weather. It also aids the bees very much in preventing the entrance of robbers.

The bottom board should be suspended by staples and hooks near each corner of the hive, in such a manner as to afford a free entrance and egress to the bees on all its sides, which will better enable then to keep their tenement clear of the moths.

There should be a button attached to the lower edge of the rear of the hive, so as to enable the Apiarian to govern the same in such a manner as to give all the air they need. or close the hive at pleasure.

The hive should have two sticks placed at equal distances, extending from front to rear. resting on the rear, with a screw drawn through the front into the end of the stick, which holds it fast in its place.

The door to the chamber should be made to fit in the rabitings of the same against the jambs, in such a manner as to exclude the 
light from the windows of the drawers, and also to prevent the entrance of the little ants. It should also be hung by butts, or fastened by a bar, running vertically across the centre of the door, and confined by staples at each end.

There should be three sheet iron slides, one of which should be nearly as wide as the chamber, and one or two inches longer than the length of the chamber. The other two should be the same length of the first, and half its width only.

All hives and all their appendages should be made exactly of a size and shape in the same apiary. The trouble of equlaizing colonies is far less than it is to accommodate hives to swarms. Much perplexity and sometimes serious difficulties occur, where the Apiarian uses different sized hives and drawers. But this part of the subject will be more fully discussed under its proper rule. 


\section{RULE II.}

ON SWARMING AND HIVING.

The Apiarian or bee owner, should bave his hives in readiness and in their places in the apiary, with the drawers in their chambers bottom up, so as to prevent entrance.

When a swarm comes forth and has alighted. cut off the limb if conveient, shake it gently, so as to disengage the bees, and let them fall gently on to the table, board, or ground (as the case may be) place the hive over them before many rise into the air, taking care at the same time to lay one or more sicks in such a manner as to raise the hive so as to give the bees rapid ingress and egress. If the bees act reluctantly in taking possession of their new habitation, disturb them by brushing them gently with a goose quill or some other instrument, not harsh, and they will soon enter. In case it is found necessary to invert the hive to receive the bees, (which is frequent, from the manner of their alighting,) then, first, secure the drawers down to the floor by inserting a handkerchief or something above them; now invert the hive and shake or brush the bees gently into it ; now turn it gently right 
end up on the table, or as the case mar be, observing the rule aforesaid.

\section{R E M A R K S .}

Bees swarm from nme o'clock in the morning to three o'clock in the afternoon on a fair day, differing in the season according to the climate. In Vermont they generally swarm from the middle of May to the fifteenth of July; in late seasons some later. I have known them to swarm as early as, seven in the morning and as late as four in the afternoon. I have also known them to come forth when it rained so hard as nearly to defeat them by heating down many to the ground which were frobably lost from their colony; and I once had a swarm come forth on the sixteenth day of August.

Experience and observation has taught that the Queen leaves the old stock first, and her colony rapidly follow. They fly about a few minutes, apparently in the greatest confusion, until the swarm is principally out of the hive. They then alight, generally on the limb of some tree, shrub, or bush, or some other place con- 
renient for them to cluster in a bunch not far from the old stock and make their arrangements for a journey to a new habitation. Perhaps not one swarm in a thousand knows where they are going until after they have left the old stock, alighted, formed into a compact body or cluster, and not then until they have sent off an embassy to search out a place for their future residence. Now if the bees are hived immediately afier they have alighted, before they send off their embassy to. seek a new tenement, they will never fly away, admitting they have sufficient room, (for $i \hat{\imath}$ is want of room that makes them swarm in the first place) and their hive is also clear of every thing that is offensive to them.

The old custom of washing hives with salt and water and other substances, to give it : pleasant effluvia, should be speedily aholished. Nothing but bees should ever be put into : hive.

When bees die, the hive should be cleared of its contents and scraped out clean, and the the chamber rubbed with cloth wet in rleas 
water; then set it in its place in the apiary, and there let it stand until wanted for use. An old hive, thus prepared, is as good as a new one for the reception of a swarm. The Apiarian shou'd examine before using to see that the hive is free from spiders and cobwebs.

When bees are not hived immediately after they have clustered in a body, they should be removed to the apiary, or several rods from the place where they alighted, as soon as they can be hived, to prevent their being found on the return of the embassy. Since $I$ have thus practised, I have never lost a swarm by flight.

Experience has taught that it is best to remove the new swarm to the place where it is intended to stand during the season, immediately after hiving. Fewer bees are lost by a speedy removal, than when permitted to stand until evening, because they are creatures of habit, and are every moment establishing themselves in their location. 'I'he longer tliey stand in the place where they are hived, the greater will be the number lost when removerl. But more of this hereafter. 
When bees are collected in drawers for the purpose of equalizing colonies, by doubling, \&c., they should be permitted to stand until evening before they are united, it being a more favorable time for them to become acquainted with each other by degrees; and the scent of the bees in the lower apartment will enter through the apertures during the night so much that there is a greater degree of sameness in the peculiar smell of the two colonies, which takes off their animosity, if they chance to have any.

No confusion or noise which is uncommon to the bees should ever be made during their swarming or hiving. The only effect of noise, ringing of bells, \&ic. that $I$ could ever discover, was, to render them more hostile and unmanageable.

When bees are treated in accordance with their true nature, they are sometimes hostile, which originates from two causes. First, some of them lie out of the hive before swarming, and some of them, in consequence of their confusion in swarming, are not apprised of the 
intention of the Queen to leave the old stock and seek a new habitation, and they sally forth with the swarm without filling their sacks with stores, which always makes them more irritable than when their stomachs are filled with food.

The Vermont hive possesses advantages in this respect, as well as others, far superior to the old box. Instead of lying out before swarming, as in the old box, they go up into the drawers, and are constantly employed in depositing the delicious fruits of their labors: and being in the hive, where they can hear and observe all the movements of the Queen, they go forth well stored with provisions suited to the peculiar contingency of the case; which ordinarily repels all their feelings of hostility.

The second reason why bees are sometimes irritable, and are disposed to sting when they swarm, is, the air is forbidding to them, by being cold or otherwise, so as to impede them in their determined emigration. In all such sases, the Apiarian should be furnished with a veil, made of millinet, or some light covering, 
which may be thrown over his hat, and let down so low as to cover his face and bosom, and fixed in such a manner as to prevent their stinging. He should also put on a pair of thick woolen stockings over his hands, thus managing them without the least danger.

A clean hive is all that is needed for a swarm of bees, with careful and humane treatment.

I know of no rule by which the exact day of their first swarming can be known with certainty. The Apiarian will estimate near the time by the number of bees in and about the hive, as it will become very much crowded.

The day of second swarming, and all after that during the same season, may be most certainly predicted as follows. Listen near the entrance of the hive in the evening. If a swarm is coming forth the next day, the Queen will be heard giving an alarm at short intervals. The same alarm may generally be heard the next morning. The observer will generally hear two Queens at a time in the same hive, the one much louder than the other. The one making the least noise is yet in her 
cell, and in her minority. The sound emitted by the Queens is peculiar, differing materially from that of any other bee. It consists of a number of monotonous notes in rapid succession, similar to those emitted by the mud-wasp when working her mortar and joining it to her cells, to raise miss-wasps. If, after all, the weather is unfavorable to their swarming two or three days while in this peculiar stage, they will not be likely to swarm again the same season.

Two reasons, and two only, can be assigned why bees ever swarm. The first is, want of room, and the second, to avoid the battle of the Queens. It is indeed true that there are exceptions. Perhaps one in a hundred swarms may come forth before their hive is filled with comb ; but from nearly forty years experience in their cultivation, I never saw an instance of it, where the hive was not full of bees at their first swarming. When the first swarm comes forth, eggs, young brood, or both, are left in the combs, but no Queen; for the old Queen always goes forth with the swarrn, and leaves 
the old stock entirely destitute. Not a single Queen, in any stage of minority, is left in the hive.

The bees very soon find themselves destitute of the means of propagating their species, for the Queen is the only female in the hive, and immediately set themselves to work in constructing several royal cells, probably to be more sure of success; take a grub (larva) from the cell of a common worker, place it in the new-made royal cell, feed it on royal jelly, and in a few days they have a Queen. Now as the egos are laid in about three litters per week, the bees, to be still more sure of succeeding in their laudable enterprize, take maggots, differing only in age, so that if more than one Queen is hatched, one will be older than the others. This fact accounts for hearing more than one Queen at the same time, because one comes out a perfect fly, while the other is a nymph, or a little younger, and has not yet made her escape from the cell where she was raised, and yet both answer the alarm of the other, the youngest more feebly than the elder. 
Bees will never swarm but once the same season, unless they make more than one Queen, immediately after the departure of the firstswarm; and not then, if the bees permit the oldest Queen to come in contact with the cell where the younger ones are growing. Queens entertain the most deadly animosity towards each other, and will commence an attack upon each other the first moment opportunity offers; the old Queen will even tear all the cradles or cells to pieces where young ones are growing, and destroy all the chrysalis Queens in the hive.

If the weather becomes unfavorable to swarming, the next day after the alarm of the Queen is heard, and continues so for several days, the oldest Queen may come in contaet with the other, or gain access to their cells; in either case the life of one of them is destroyed by the other, and the colony will not be likely to send forth another swarm the same season. If the old Queen succeeds in taking the life of the younger, or vice versa, the remaining nymphs will be likely to share the 
same fate of her martyred sisters, by the hand of the reigning Queen, who considers all others in the same hive as her competitors.

Second swarms would be as large and numerous as any others, if it was not the fact, that they come forth to avoid the battle of the Queens. Bees are very tenacious to preserve the lives of their sovereigns, particularly those of their own raising; and when they find they have more than one in the hive, they will guard each so strong as to prerent, if possible, their coning within reach of each other. They being thus strongly guarded to prevent the fight, is unquestionably the cause of their giving the alarm, as described in the foregroing article. The knowledge of the existence of another Queen in the same hive inspires them with the greatest uneasiness and rage; and when the oldest one finds herself defeated in gaining access to her competitor, she sallies forth with as many as see fit to follow her, and seeks a new habitation.

The drawers should be turned over, so as wo let the bees into them as soon as they have 
built their combs nearly to the bottom of the hive. If the swarm is so large that the lower apartment will not hold all of them, they should be let into one or both of the drawers, at the time of hiving; otherwise they may go off for want of room.

\section{R U L E I I I.}

ON VENTILATING THE HIVE.

Graduate the bottom board at pleasure, by means of the button or otherwise, so as to give them more or less air, as the circumstances may require.

R $E \mathrm{MARK}$.

Bees require more air in order to enable them to endure the heat of summer and the severity of winter, than at any other time. If they are kept out in the cold, they need as much air in the winter as in the heat of summer. It is in a mild temperature only, that it is safe to keep them from the pure air. If placed below frost in a dry sand bank, they: 
seem to need scarcely more than is contained in their hive at the time they are buried, during the whole winter. If kept in a clean, dry cellar, the mouth, so contracted as to keep out mice, gives them enough. But if they are kept in the apiary, the bottom board should be suspended as low as in heat of summer. My stocks have wintered best, which have had at least one inch space betwixt the bottom board and the lower edges of the hive.

\section{R ULE I V.}

ON PREVENTING ROBBERIES.

At the moment it is observed, that robbers are within, or about the hive, raise the bottom board so near the edge of the hive as to prevent the ingress or egress of the bees, and stop the mouth or common, entrance. At the same time take care that a small space on all sides of the hive be left open, so as to afford them all the air they need. Open the mouth' only at evening and close early in the morning, before the robbers renew their attack. 
R E M A R I S .

Bees have a peculiar propensity to rob each other, and every precaution, necessary to prevent it, should be exercised by the cultivator. Families in the same apiary are more likely to engage in this unlawful enterprize than any others, probably because they are located so near each other, and are more likely to learn their comparative strength. I never could discover any intimacy between colonies of the same apiary, except when they stood on the same bench; and then, all the social intercourse seems to subsist between the nearest neighbors only.

Bees are not likely to engage in warfare and rob each other, except in the spring and fall, and at other times in the season, when food is not easily obtained from blossoms.

Bees do not often engage in robbery in the spring, unless it is in such hives as have had their combs broken by frost or otherwise, so is to cause the honey to drip down upon the bottom board. Much care should be exercised by the Apiarian to see that all such hives 
are properly ventilated, and at the same time closed in such a manner as to prevent the entrance of robbers in the day-time, until they have mended the breach, so as to stop the honey from running.

Clear water should be given them every day, sn long as they are kept in confinement.

I have known many good stocks to be lost in the spring, by being robbed; and all for want of care. Bees rob each other when they can find but little else to do; they will rob at any time when frost has destroyed the flowers, or the weather is so cold as to prevent their collectig honey from them. Cold, chilIy weather prevents the flowers from yielding honey without frost, as was the case in the summer of 18.35 , in many places.

Bees need but little air at any time when they rob, and yet more is necessary for them, when confined by compulsory means, than at any other time. When deprived of their liberty, they soon become restless, and use their best efforts to make their way out of the hive; hence the importance of leaving a small space all around 
the bottom, to admit air and to prevent their melting down.

\section{R U L E V.}

ON EQUALIZING COLONIES.

Hive one swarm in the the lower apartment of the hive; collect another swarm in a draw$\mathrm{er}$, and insert the same in the chamber of the hive containing the first. Then, if the swarms are small, collect another small swarm in another drawer, and insert the same in the chamber of the hive containing the first, by the side of the second. In case all the bees from either of the drawers, amalgamate and go below with the first swarm and leave the drawer empty, then it may be removed, and another small swarm added in the same manner.

RE M A R K .

It is of prime importance to every bee cultivator, that all his colonies be made as near equal in numbers and strength, as possible. Every experienced bee-master must be aware that small swarms are of but little profit to 
their owner. Generally, in a few days after they are hived, they are gone; no one can trace their steps; some suppose they have fled to the woods, others that they were robbed; but, after all, no one is able to give any satisfactory account of them. Some pieces of comb only are left, and perhaps myriads of worms and millers finish off the whole. Then the moth is supposed to be their destroyer, but the true history of the case is generally this: The bees become discouraged, or disheartened, for want of numbers to constitute their colony, abandon their tenement, and join with their nearest neighbors, leaving their combs to the merciless depredations of the moth. They are sometimes robbed by their adjoining hives, and then the morhs finish or destroy the combs and bread.

Second swarms are generally about half as large as the first, and third swarms half as large as second ones.

Now if second swarms are doubled, so as to make them equal in number with the first, she owner avails himself of the advantage of a 
strong colony, which will not be likely to become disheartened, for want of numbers, nor overcome by robbers from stronger colonies.

It is far less trouble, and less expense, for the bee owner to equalize his colonies, than to prepare hives and drawers of different sizes to fit colonies.

When colonies and hives are made as near alike as possible, many evils are avoided, and many advantages realized; every hive will fit a place in the apiary, every drawer a hive, and every bottom board and slide will in any case be used without mistakes.

Swarms may be doubled at any time before they become so located as to resume their former hostility, which will not be discovered in less than three or four days. Now bees are provided with a reservoir, or sack, to carry their provision in; and when they swarm, they go loaded with provision suited to their emergency, which takes off all their hostility towards each other; and until these sacks are amptied, they are not easily vexed, and as they are compelled to build combs before they 
can empty them, it takes them several days. I have doubled, at a fortnight's interval in swarming, with entire success. The operation should be performed within two or three days, at the farthest four days. The sooner it is done, the less hazardous is the experiment.

As a general rule, second swarms only should be doubled. Third and fourth swarms should always have their Queen taken from them and the bees returned to the parent stock, according to Rule 10.

\section{RULE V I.}

ON REMOVING HONEY.

Insert a slide between the drawer and floor to the chamber, so far as to cut off all communication between the lower apartment and the drawer. Insert another slide between the first slide and the drawer. Now draw out the box containing the honey. Set the drawer on its window end, a little distance from the apiary, and remove the slide. Now supply the place of the drawer, thus removed, with 
an empty one, and draw the first inserted slide.

R E M A R K S .

Care must be exercised in performing this operation. The apertures through the floor into the chamber must be kept closed during the process, so as to keep the bees from rushing up into the chamber when the box is drawn out. The operator must likewise see that the entrances into the drawer are kept covered with the slide, in such a manner as to prevent the escape of any of the bees, unless he is willing to be stung by them. If the bees are permitted to enter the chamber in very warm weather, they will be likely to hold the occupancy of it, and build comb there, which will change the hive into one no better than an old fashioned box.

I have succeeded best in removing honey by the following method, to wit: Shut the window blinds so as to darken one of the rooms in the dwelling house-raise up one casement of a window - then carry the drawer and place the same on a table, or stand, by the window, 
on its light or glass end, with the appertures towards the light. Now remove the slide, and step immediately back into the dark part of the room. The bees will soon learn their true condition, and will gradually leave the drawer, and return home to the parent stock; thus leaving the drawer and its contents for their owner; not however until they have sucked every drop of running honey, if there should chance to be any, which is not often the case, if their work is finished.

There are two cases in which the bees manifest some reluctance in leaving the drawer. The first is, when the combs are in an unfinished state, some of the cells not sealed over. The bees manifest a great desire to remain there, probably to make their stores more secure from robbers, by affixing caps to the uncovered cells, to prevent the effluvia of running honey, which is always the greatest temptation to robbers.

Bees manifest the greatest reluctance in leaving the drawer, when young brood are removed in it, which never occurs, except in 
such drawers as have been used for feeding in the winter or early in the spring. When the Queen has deposited eggs in all the empty cells below, she sometimes enters the drawers; and if empty cells are found, she deposites eggs there also. In either case, it is better to return the drawer, which will be made perfect by them in a few days.

Special care is necessary in storing drawers of honey, when removed from the care and protection of the bees, in order to preserve the honey from insects, which never make sweet, but are great lovers of honey, particularly the ant. A chest, made perfectly tight, is a good store-house.

If the honey in the drawers is to be preserved for winter use, it should be kept in a room so warm as not to freeze. Frost cracks the combs, and the honey will drip as soon as warm weathel commences. Drawers should be packed with their appertures up, for keeping or carrying to market. 


\section{R ULE VII.}

THE METHOJ OF COMPELLING SWARMS TO

MAKE AND KEEP EXTRA QUEENS, FOR THEIR APIARIAN, OR OWNER.

Take a drawer containing bees and brood comb, and place the same in the chamber of an empty hive; taking care to stop the entrance of the hive, and give them clean water, daily, three or four days. Then unstop the mouth of the hive, and continue to them their liberty. The operator must observe Rule 6 in using the slides.

\section{R E M A R K S .}

The prosperity of every colony depends entirely on the condition of the Queen, when the season is favorable to them.

Every bee-master should understand their nature in this respect, so as to enable him to be in readiness to supply them with another Queen when they chance to become destitute-

The discovery of the fact, that bees have the power to change the nature of a grub (larva) of a worker to that of a Queen, is at- 
tributed to Bonner. But Bonner, nor the indefatigable Huber, nor any other writer, to my knowledge, has gone so far in the illustration of this discovery as to render it practicable and easy for common people to avail themselves of its benefits.

The Vermont hive is the only one, to my knowledge, in which bees can be compelled to make and keep extra Queens for the use of their owner, without extreme difficulty, as well as danger, by stings, in attempting the experiment.

The idea of raising her royal highness, and elevating and establishing her upon the throne of a colony, may, by some, be deemed altogether visionary and futile; but $\mathbf{I}$ will assure the reader, that it is easier done than can be described. I have both raised them, and supplied destitute swarms repeatedly.

When the drawer containing bees and brood comb, is removed, the bees soon find themselves destitute of a female, and immediately set themselves to work in constructing one or more royal cells. When completed, which is. 
commonly within forty-eight hours, they remove a grub (larva) from the worker's cell. place the same in the new made Queen's cell, feed on that kind of food which is designed only for Queens, and in from twelve to sixteen days they have a perfect Queen.

As soon as the bees have safely deposited the grub in the new made royal cell, the bees may have their liberty. Their attachment to their young brood, and their fidelity to their Queen, in any stage of its minority, is such, that they will never leave nor forsake them, and will continue all their ordinary labors, with as much regularity as if they had a perfect Queen.

In making Queens in small boxes or drawers, the owner will not be troubled by their swarming the same season they are made. There are so few bees in the drawer, they are unable to guard the nymph Queens, if there are any, from being destroyed by the oldest, or the one which escapes from her cell first.

In examining the drawer, in which I raised an extra Queen, I found not only the Queen, 
but two royal cells, one of which was in perfect shape; the other was mutilated, probably by the Queen which came out first. Now when there are so few bees to guard the xymphs, it would not be very difficult for the oldest Q!ıeen to gain access to the cells, and destroy all the minor Queens in the drawer.

When a drawer is removed to an empty hive, for the purpose of obtaining an extra Queen, it should be placed some distance from the apiary, the better to prevent its being robbed by other swarms. When it is some distance from other colonies, they are not so likely to learn its comparative strength. There is but little danger however, of its being robbed, until after the bees are out of danger of losing their Queen, which generally occurs in the swarming season.

The Queen is sometimes lost, in consequence of the young brood being too far adwanced at the time of the departure of the old Queen with her swarm. If the grubs had advanced very near the dormant or chrysalis state, before the bees learnt their necessity for 
a Queen, and the old Queen neglected io leave eggs, which is sometimes the case; then it would be impossible for the bees to change their nature, and the colony would be lost, unless supplied with another.

\section{R U L E VIII.}

ON SUPPLYING SWARMS, DESTITUTE OF A QUEEN, WITH ANOTHER.

Take the drawer from the hive, which was placed there according to Rule 7 , and insert the same into the chamber of the hive to be supplied; observing Rule 6 in the use of the slides.

REM A R K .

Colonies destitute of a Queen may be supplied with another the moment it is found they have none; which is known only by their actions.

Bees, when deprived of their female sovereign, cease their labors; no polen or beebread is seen on their legs; no ambition seems 
to actuate their movements; no dead bees are drawn out; no deformed bees, in the various stages of their minority, are extracted, and dragged out of their cel's, and dropped down about the hive, as is usual among all healthy and prosperous colonies.

Colonies that have lost their Queen, when: standing on the bench beside of other swarms, will run into the adjoining hive without the least resistance. They will commence their emigration by running in confused platoons of hundreds, from their habitation to the next aljoining hive. They immediately wheel aloout and run bome again, and thus continue, sumetimes for several days, in the greatest confusion, constantly replenishing their neighbor's hive, by enlarging her colony, and, at the same time, reducing their own, until there is not a single occupant left; and remarkable is it is, they leave every particle of their stires for their owner or the depredations of the moth.

Colonies loose their Queens more frequentIf during the swarming season than any other. 
In the summer of 1830, I lost three good stocks of bees in consequence of their losing their Queens, one of which was lost soon after the first swarming, the two others not many days after the second swarming, all of which manifested similar actions, and ended in the same results, which will be more particularly explained in remarks on Rule 10.

The Queen is sometimes lost, when she goes forth with a swarm, in consequence of being too feeble to fly with her young colony ; in which case the bees return to their parent stock, in a few minutes. In fact all occurrences of this kind originate in the inability of the Queen. If she returns to the old stock: the swarm will come out again the next day, if the weather is favorable. If the Queen is too feeble to return, and the A piarian neglects to look her up, and restore her to her colony agrain, (which it is his imperative duty to do,) the bees will not swarm again until they have made another, or are supplied, which may be done immediately by giving them any swar $4 *$ 
Queen. I have done it with entire success, and never failed in the experiment.

The Queen, when lost in swarming, is easily found, unless the wind is so strong as to have blown her a considerable distance. A few bees are always found with her, which probably serve as her aids, and greatly assist the A piarian in spying her out. She is frequently found near the ground, on a spire of grass, the fence, or any place most convenient for her to alight, when her strength fails her. I once had quite a search for her majesty, without much apparent success. At the same time, there were flying about me a dozen or more common workers. At last her royal highness was discovered, concealed from my observation in a fold of my shirt sleeve. I then returned her to her colony, which had already found their way home to the parent. stock.

The Queen may be taken in the hand without danger, for she never stings by design, except when conflicting with another Queen; 
and yet she has a stinger at least one third longer, but more feeble than a worker.

The Queen is known by her peculiar shape, size, and movements. She differs but little in color from a worker, and has the same number of legs and wings. She is much longer than any of the bees. Her abdomen is very large and perfectly round, and has an additional number of folds, which makes her known to the observer the moment she is seen. The wings and proboscis are short. Her movements are stately and majestic. She is much less in size, after the season for breeding is over. She is easily selected from among a . swarm, at any season of the year, by any one who has often seen her.

\section{R U L E I X.}

ON MULTIPLYING COLONIES TO ANY DESIRABLE EXTENT, WITHOUT THEIR SWARMING.

The large drawer, No. 1, should always be used for this purpose. Insert slides, as in 
Rule 6, and remove the drawer containing bees and brood comb; place the same in the chamber of an empty hive ; stop the entrances of both the new and old hives, taking care to give them air, as in Rule 4. Give clean water daily, three or four days. Now let the bees, in both hives, have their liberty.

\section{R E M A R K S.}

This operation is both practicable and easy, and is of prime importance to all cultivators, who wish to avoid the necessity of hiving them when they swarm; and yet it will not prevent swarming, except in that part of the divided colony which contains the Queen at the time of their separation. The other part being compelled to make another Queen, (and they generally make two more) will be likely to swarm to avoid their battle, as explained in Remarks on Rule 2. The hive containing the old Queen may swarm for want of room; but, at any rate, in performing the operation, it has saved the trouble of hiving one swarm, and prevented all danger of their fiight to the woods.

Muitiplying colonies by this rule is a per- 
fectly safe method of managing them, admitring they are not allowed to swarm themselves so low as to leave unoccupied combs, which will be explained in Remarks on Rule 10.

\section{R U L E X}

GN PREVENTING THE DEPREDATIONS OF THE MOTH.

All such stocks as are infested with the moth, will manifest it as soon as warm weather commences in the spring by dropping some of the worms upon the bottom board. Let the Apiarian clean off the bottom board every other morning; at the same time strew on a spoonful or two of fresh, pulverized salt.

Immediately after a second swarm has come forth from a hive, the same season, the old stock should be examined; and if swarming has reduced their numbers so low as to leave unoccupied combs, the Apiarian should take the Queeu from the swarm, and let them return to the old stock. In case they remain in a cluster, hive them in a drawer, and return them immediately. 
Third and fourth swarms should always have their Queens taken from them and the bees returned to the parent stock.

\section{R E M A R K S .}

"This insect is a native of Europe; but has found its way into this country, and naturalized itself here."-Tнатснеr.

This unwelcome visitor has interested the attention and called forth all the energies of the most experienced A piarians of our country, and of many of the greatest naturalists in the world. Their movements have been observed and scrutinized by the most learned, their nature has been studied, various experiments have been tried to prevent their depredations; but after all the monster in gaudy hue marches onward, committing the greatest havoc and devastation, with but little molestation.

I have lost my whole stock at least four times since 1808, as I supposed by the moth. I tried all the experiments recommended in this and other countries, that came to my knowledge; but, after all, I could not prevent their ravages. 
In 1830, I constructed a hive (which has since been patented) which I supposed would afford all the facilities for managing bees in every manner that their nature would admit of, and at the same time render their cultivation most profitable to their orwner. By constructing windows of glass, on every side of the hive, nearly the size of its sides, and darkening them by closing doors on the outside of the windows, which may be opened at pleasure, I have been able to discover many important facts, both in relation to the nature and economy of the bee, and its enemy the moth; but, probably, much yet remains to be learned concerning both.

The moth, when first discovered by the common observer, is a white worm or maggot, with a reddish crusted head, and varies in size according to its living. Those which have full and unmolested access to the contents of a hive, will frequently grow as large as a turkey quill, and an inch and a half in length. Others are scarcely an inch in length when full grown. They have sixteen short 
legs, and taper each way from the centre of their bodies to their head and exterior or abdomen.

The worms, like the silk worm, wind themselves into a cocoon, and pass the dormant (chrysalis) state of their existence, and in a few days come out of their silken cases perfect winged insects or millers, and are soon ready to deposit their eggs, from which another crop will be raised.

The miller, or perfect moth, is of a greyish color, from three fourths of an inch to an inch in length. They usually lie perfectly still in the day time, with their head downwards, lurking in and about the apiary. They enter the hive in the night, and depposite their eggs in such places as are uncovered, of course unguarded, by the bees. These eggs hatch in a short time, varying according to circumstances, probably from two or three days to four or five months. At an early stage of their existence, while yet a small worm, they spin a web, and construct a silken shroud, or foriress, in which they envelope themselves, and 
form a sort of path, or gallery, as they pass onward in their march; at the same time being perfectly secure from the bees, in their silken case, which they widen as they grow larger; with an opening in their front only, near their head; they commit the greatest havoc and devastation on the eggs, young bees and all, that come in their way as they pass.

When the moth has arrived to his full state of maturity, he makes preparation to change to a miller, by winding into a cocoon, as has been already explained. The miller is surprisingly quick in all its movements, exceeding by far the agility of the quickest bee, either in flight or on its legs. Hence the enemy becomes so formidable that the bees are easily overcome and soon fall a sure prey to him.

Now in order to remedy the evils of the moths, and prevent their ravages, and at the same time aid the bees in their prosperity, and make them profitable to their owner, I found it necessary to use a hive differing materially 
from the old box, and commenced operations in the one already referred to, (called the Vermont hive,) in a course of experiments which have produced results perfectly satisfactory. From six years experience in its use, I have not the least doubt that bees may be managed to the best advantage, and without ever being materially injured by the moths.

A beehive should be made in a perfect workmanlike manner, so as to have no open joints; the boards should be free from shakes and cracks, because the bees will make their tenement perfectly tight, so as to exclude light and air, by plastering up all such places as are left open by the workman, with a kind of mortar, or glue, of their own make, which is neither honey nor wax, but is very congenial to the growth of the worms in the first stages of their larva state, and being secured from the bees by the timber, in a short time they are able to defend themselves by a silken shroud.

Now the miller enters the hive and makes 
an incision into the bee-glue, or cement, with her abdominal sting, and leaves her eggs. These eggs hatch there, and the brood subsist on the glue until they have arrived so far toward maturity as to enable them to encase themselves in a silken shroud; and then they move onward.

Now unless the bees chance to catch him by the collar, or nape of his neck, while feeding, and drag him out of his place of concealment, they will be compelled to cut away the combs all around his silken path, or gallery, and drag out the worm and his fortress all together. At the same time, the bees are compelled to cut away the combs so far as to destroy many of their young brood in making room to remove the annoyance. I have known them to cut away their combs from four to eight or ten inches to remove this silken shroud, and have known them to cut and drag out their only remaining Queen before she was transformed to the perfect fly, which occasioned the entire loss of the whole colony. 
Repeated experiments have demonstrated the fact, that placing bees on the ground, or high in the air, is no security against the moths. I have lost some of my best stocks by placing them on the ground, when those on the bench were not injured by them. I have made a groove in the bottom board, much wider than the thickness of the boards to the hive, and filled the same with loam, I then placed the hive on the same, in such a manner as to prevent any crack or vacancy for the worms; and yet, in raising the hive four weeks afterwards, I found them apparently full grown all around the hive in the dirt. I have found them very plenty in a tree ninety feet from the ground.

The best method, in common practice, to prevent the depredations of the moth, is, to suspend the bottom board so far below the lower edge of the hive as to give the bees free entrance and egress all around the same during the moth season, or to raise the hive, by placing under it little blocks at each corner, which produces nearly the same effect. But I know of but one rule, which is an infal. 
lable one, to prevent their depredations, and that is this: keep the combs well guarded by bees. See Rule 10.

Large hives, that never swarm, are never destroyed by the moth, unless they lose their Queen, melt down, or met! with some casualty, out of the ordinary course of managing them. They are not often in the least annoyed by them, unless there are bad joints, cracks, or shakes, so as to afford some lurking places for the worms. The reason for their prosperous condition is obvious. The stock of bees are so numerous that their combs are all kept well guarded during the moth season, so that no miller can enter and deposit her eggs.

Hives made so snall as to swarm, are liable to reduce their colonies so small as to leave combs unguarded, especially when they swarm three or lour times the same season. All swarms, after the first, sally forth to avoid the battie of the Queens; constantly making a greater draft, in proportion to the number left, until the combs are partly exposed, which gives the miller free access to their edges.- 
The seeds of rapine and plunder are thus quickly sown, and soon vegetate, and fortify themselves by their silken fortress, before the bees are aware that their frontiers are invaded. While the moths are thus engaged in establishing their posts on the frontiers of the bees, the latter are constantly and indefatigably engaged in providing themselves with another Queen, to supply the place of the old one, which has departed with a swarm, and raising young bees to replenish their reduced colony. Now as the moths have got possession of the ground on their frontiers, it requires a tremendous effort on the part of the bees to save their little colony from a complete overthrow.

If late, or second and third swarms, are always returned immediately according to the rule, the combs are kept so guarded that the moths are compelled to keep their distance, or be stung to death before they can accomplish their purposes.

Hives made so large as not to swarm may loose their Queen, and then they will-aban- 
don their habitation and emigrate into the adjoining hive, leaving all their stores to their owner, which, unless immediately taken care of, the moths will not fail to destroy.

The moths are often complained of when they are not guilty. Hives are frequently abandoned by their occupants, in consequence of the loss of their Queen, umnoticed by any observer, and before any thing is known of their fate, the hive is destitute of bees, and filled with moths.

In the summer of 1834 , one of my neighbors hadi a very large hive that never swarmed, which lost their Queen; and in the course of a fer days the bees eutirely vacated their tenement, and emigrated into an adjoining hive, leaving the whole of their stores, which amounted to $215 \mathrm{lbs}$. of honey in the comb. No young bees or moths were discovered in the hive. Instances of this kind frequently occur, and the true cause is unknown, from inattention.

The Queen may be superanuated, or may become diseased in the breeding season, so as 
to render her unfruitful; or she may die of old age. In either case, the colony will be lost, unless supplied with another Queen as explained in Remarks on Rule 8; for when the Queen becomes unfruitful by either of the foregoing causes, the bees are not apprized of the loss which will in future be sustained by them, until after the means of repairing the same are gone beyond their reach. All the grubs may have passed the various stages of their transformation, or at least advanced so far towards the perfect insect, that their nature cannot be changed to a Queen.

The Queen is much more tenacious of life than any other bee, and may live to a great agre. But one Queen existis in the same live any great length of time. When there are more than one, the peculiar sound of each, as explained in Remarks on Rule 2, is heard by the other, which always results in a batile between them, or the issue of a swarm in the course of a day or two.

Bees, when placed in a dark room in the upper part of the lowso, or sone out-house, 
are easily culcirated a short time with little trouble, and are sometimes made profitable to their owner; but as they are liable to some of the same casualties as those kept in swarming hives, they cannot be as profitable.

Large colonies nerer increase their stock in proportion to the swarming colonies. There is but one female in a large colony, and they can do but little more in raising young bees than to keep their stcck good by replenishing thom as fast as they die off or are destroyed by the Lirds, reptiles and insects, which are great admirers of them and sometimes swallow them by dozens. Now if it requires five swarming colonies to be equal in number to one first described, it is not difficult to inagine that five times as many bees may be raised by the swarming colonies; for one Queen will probably lay as many cgys as another.

The swarming hives are more liable to be destroyed by the moth during the swarming scason, and no other, if the hives are kept well replenished with bees according to Rule 10. 


\section{RULE XI.}

ON FEEDING BEES.

If it is found that a swarm need feeding, rake off the bottom loard, and hitch on the feeder, well stored with good honey, while the weather is warm in October.

The Apiarian should use the same precaution in feeding, as directed in Rule 4, to prevent robberies.

RE M A R K S .

The best time to feed is in the fall, before cold weather commences. All hives should be weighed, and the weight marked on the hive before bees are hived in them. Then, by weighing a stock as soon as frost has killed the blossoms in the fall, the Apiarian will be able to form a just estimate of their necessities. When bees are fed in the fall, they will carry up and deposite their food in such a manner as will be convenient for them in the winter.

If feeding is neglected until cold weather. 
the bees must be removed to a warm room, or dry cellar, and then they will carry up their fond, generally, no faster than they consume it.

A feeder should be made the same size of the bottom of the hive, and in such a manner as to fit with its floor level, when hitched on like the bottom board. It should be of suffcient depth to lay in broad comb, filled with honey, without coming in contact with the combs of the hive. If strained honey without combs is used for feeding, a float, perforated with many holes, should be laid over the whole of the honey in the box, or feeder, so as to prevent any of the bees from drowning; and at the same time, this float should be so thin as to enable them to reach the honey. It should also be made so small that it will settle down as fast as the honey is removed by the bees. As soon as warm weather commences in the spring, the feeder may be used, Sinall drawers cannot be depended on as feeders, except in the spring and summer, unless they are kept so warm that the vapor of the 
bees will not freeze in them. It would be extremely hazardous for the bees to enter a frosty drawer. They will sooner starve, than attempt the experiment. Drawers may be used withost danger from robbers, but when the feeder is used, rob!bers must be guarded against as directed in Rule 4 .

Care should be exercised, in fall feeding, to supply them with good honey, otherwise the colony may be lost before spring by disease. Poor honey may be given them in the spring, at the time when they can obtain and provide themselves with medicine, which they, only. best understand.

Sugar dissolved, or molasses, may be used in the spring to some advantage, but cught not to be substituted for honey, when it can be obtained.

Bees sometimes die of starvation, with plenty of honey in the hive at the sam : time. In cold weather they crowd together in a small compass in order to keep warm; and then their breath and steam collect in frost, in all parts of the hive, except in the segion they 
occupy. Now unless the weather moderates so as to thaw the ice, the bees will be compelled to remain where they are located until their stores are all consumed that are within their reach. One winter we had cold weather ninety-fonr days in succession, during which time the beos could not move from one part of the hive to another. I examined all my hives on the eighty-third day, and on the ninetieth day I found four swarms dead. I immediately cxamined for the cause, which was, as already stated. I then carried all my hives into a warm room and thawed them, so that the bees could move. Some hives that I supposed were dead, revived; some few swarms I found nearly. destitute of stores, which I carried into the cellar, turned them bottom up, cut out a few of the combs, so as to make room to lay in combs filled with honey, which served as good feeders. 


\section{RULE XII.}

ON WINIERING BEES.

On the near approach of winter, as soon as the bees bave receded from the drawers and gone below, insert a slide, take out the drawers, and supply their places with empty ones, bottom up. Suspend the bottom board at least half an inch below the lower edre of the hive. Clean off the bottom board as often as the weather changes from cold to warm, giv ing them nearly as much air as in summer. Close no dowrs upon tiem, unless they are kept in a spacious room and in such a place that the breath and steam of the bees will not freeze.

REMARIS .

Various methods have been practised by different individuals. Some have buried them. in the ground, others kept them in the cellar, chamber, \&c. One course only will be observed in this place. 


\section{R U L E X I I I.}

ON TRANSFERRING SIVARMS.

This operation should never be effected by compulsion.

First Method. Insert drawer No. 1 into the chamber of the hive, to be trans rred as early as the first of May. If the bees fill the drawer, they will recede from the lower apartment and winter in the drawer. As carly in the spring as the bees carry in bread plentifully on their legs, remove the drawer, which will contain the principal part of the bees, to an empty hive. Now remove the oid hive a few feet in front, and place the new one, containing the drawer, where the old one stood. Now turn the old hive bottom up. If there are any bees left in the old hive, they will soon return and take possession of their new habitation.

Second Method. Take drawer No. 1, well filled by any hive the same season, insert the same into the chamber of the hive, to be transferred in September, (August would be better.) If the bees need transferring, they will repair to the drawer and make the same: 
their winter quarters. Then proceed in the spring as directed in the first method.

\section{R E M A R K S .}

This management should excite a deep interest in every cultivator, both in a temporal and moral point of view. Temporal, because the lives of all the bees are preserved; moral, berause we are accountable to God for all our acts. We are not to be justified in taking the lives of animals or insects, which are but lent blessings, uniess some benefit to the owner can be derived from their death, which will ontweigh the evils resulting from such a sacrifice. Duty compels me to protest, in the strongest terms and feelings, against the inhuman practice of taking the lives of the most industrous and comforting insects to the wants of the human family by fire and brimstone.

When bees have occupied one tenement for several years, the combs become thick and filthy, by being filled up with old bread and cocoons, made by the young bees when transformed from a larva to the perfect fly. 
Bees always wind themselves in their cells. in a silken cocoon, or shroud, to pass their torpid and defenceless (chrysalis) state. These cocoons are very thin, and are never removed by the bees. They are always cleaned immediately aiter the escape of the young bees. and others are raised in tlie same cells. Thus a number of bees are raised, which leaves an additional cocoon as often as the transformation of one succeeds that of another, which often occurs in the courso of the season. Now in the course of a few ycars the cells become so contracted, in consequence of being thus filled up, that the bees come forth but mere dwarfs and sometimes cease to swarm. Combs are rendered useless by heing filled up with old bread, which is never used except for feeding young bees. A greater quantity of this brend is stored up yearly than is used by them, and in a few years they have but little room to perform their ordinary labors. Hence the necessity of transferring them, or the inhuman sentence of death must be passed upon them, not by being hung by the neck until they are 
dead, but by being tortured to death by fire and brimstone.

It is obvious to every cultivator that old stocks should be transferred. I have repeatedly transferred them in the most approved manner, by means of an apparatus constructed for that purpose; but the operation always resulted in the loss of the colony afterwards, or a swarm which would have come from them.

When it is necessary to transfer a swarm, insert drawer No. 1 into their chamber in the spring, say the first of May. If they fill the drawer, let it remain there; if they need to be changed to a new hive, they will recedo from the lower apartment and make the drawer their winter quarters, which should remain until warm weather bas so far advanced as to afford them bread. Then they may be removed to an empty live, as directed in the Rule. Now the drawer contains no bread, and should remain in the old stock until the bees can provide themsevles with a sufficient ģuantity of that article to feed their young 
bees with; for bread is not collected early enough and in sufficient quantities to feed their young as much as nature requires. If the bees fail in filling the drawer, one should be used that is filled by another swarm.

\section{GENERAL OBSERVATIONS.}

The reader might have expected many things demonstrated in this work, which are omitted by design.

The structure of the worker is too well understood by every owner of bees to need a particular description. So also of the drone; and the Queen has already been sufficiently described to enable any one to select her out from among her subjects. If any further description is desired, the observer can easily satisfy himself by the use of a microscope. Every swarm of bees is composed of three classes or sorts, to wit : one Queen or female, drones or males, and neuters or workers. The 
Queen is the only female in the hive, and lays all the eggs from which all the young bees are raised to replenish their colony. She possesses no authority over them, other than that of influence, which is derived from the fact, that she is the mother of all the bees; and they, being endowed with knowledge of the fact that they are wholly dependent on her to propagate their species, treat her with the greatest kindness, icnderness and reverence, and manifest at all times the most sincere attachment to hor by feeding and guarding her from all danger.

The govermment of a hive is nearer republican than any other, because it is administeret in exact accordance with their nature. It is their peculiar natural instinct, which promptis them in all their actions. The Queen lias no more to do with the government of the live than the other bees, inless influenee may be called government. If she funds empty cells in the hive, during the breeding scason, she will deposit eggs there, because it is her naiure to do so; and the nature of the workers 
prompts them to take care and nurse all the young larve, labor and collect food for their sustenance, guard and protect their habitations and do and perform all things, in due obedience, not to the commands of the Queen, but to their own peculiar instinct.

The drone is probably the male bee, notwithstanding the sexual union has never been witnessed by any man; yet so many experiments have been tried, and observations made, that but little doubt can be entertained of its truth. That the sexual intercourse takes place high in the air, is lighly probable from the fact, that other insects of the fly tribe do copulate in the air, when on the wing, as I have repeatedly seen. The doctrine that the drone is the malo bee, is probable from the fact that they are not all killed at once; but that at least one in cuch hive is pemitted to live several months ufior the general massacre.

I esanined four swams, whose colonies were strong and numerous, three months after the gencral massacre of the drones, and in 
three hives I found one drone each; the other was probably overlooked, as the bees were thrown into the fire as fast as they were examined. But there are many mysterious things concerning them, and much might be written to little purpose ; and as it is designed to go no further in illustrations than is necessary to aid the Apiarian in good management, many little speculations have been entirely omitted in the work, and the reader is referred to the writings of Thatcher, Bonner, and Huber, who are the most voluminous and extensive writers on bees within my knowledgre.

Bees are creatures of habit, and the exercise of caution in managing them is required. A stock of bees should be placed where they are to stand through the season before they form habits of location, which will take place soon after they commence their labors in the spring. They learn their home by the objects surrounding them in the immediate ricinity of the hive. Moving them, (unless they are carried beyond their knowledge,) is often fatal to them. The old bees forget their ncw loca- 
sion, and on their return, when collecting stores, they haze about where they formerly stoori, and perish. I have known some fine stocks ruined by moving them six feet and from that to a mile and a half. It is better to move them before sirarming than afterwards. The old bees only will be lost. As the young ones are constantly hatching, their habits will be formed at the new stand, and the combs will not be as likely to become vacated, so as to afford opportunity to the moths to occupy any part of their ground.

Srrams, when first hived, may be moved at pleasure without loss of bees, admitting they are all in the hive; their habits will be formed in exact proportion to their labors. The first bee that empties his sack and goes forth in search of food, is the one whose habits are first established. I have observed many bees to cluster near the place where the hive stood, but a few hours after hiving, and perish. Now if the swarm had been placed in the apiary, immediately after they were hived, the uunber of bees found there would have been less. 
Bees may be moved at pleasure at any season of the year, if they are carried several miles, so as to be beyond their knowledge of country. They may be carried long journeys by traveling nights, only, and affording them opportunity to labor and collect fond in the day time.

The importance of this parc of bee-management is the only apology I can make for dwelling so long on this point. I have known men of high attainments in literary knowledge, as well as other's, to suffer serious losses, in consequence of moving their bees after they were well settled in their labors.

Bees should never be irritated, under any pretence whatever. They should be treated with attention and kindness. They should be kept undisturbed by cattle and all other annoyances, so that they may be approached at any time with safety.

An apiary shoulu be so situated, that swarming may be observed, and at the same time where the bees can obtain food easily, and in the greatest abuna'ince. 
It has been a general practice to front beehouses either to the east, or south. This doctrine should be exploded with all other whims. Apiaries should be so situated as to be convenient to their owner, as much as any other buildings.

I have them front towards all the cardinal points, but can distinguish no difference in their prosperity.

Young swarms should be scattered as much as convenient during the summer season, at least eight feet aprart. They should be set in a frame and so covered as to exclude the sun and weather from the hive.

It is not surprising, that this branch of rural economy in horticulture, in consequence of the depredations of the moth, is so much neg. lected. Notwithstanding, in some parts of our country, the business of managing bees has been entirely abandoned for years, I am confident they may be cultivated in such a manner as to render them more profitable to their owners, than any branch of agriculture, in proportion to the capital necessary to be 
invested in their stock. They are not taxable property, neither does it require a large land investment, nor fences, neither does it require the owner to labor through the summer to support them through the winter. Care is, indeed, necessary, but a child, or a zuperanuated person can perform most of the duties of an A piarian. The cobwebs must be kept away from the immediate vicinity of the hive, and all other annoyances removed.

The management of bees is a delightful employment, and may be pursued with the finest sticcess in cities and villages, as well as towns and country. It is a source of great amusement, as well as copfort and profit. They collect honey and bread from mosi kinds of forest trees, as well as garden flowers, orchards, forests, and fields; all contribute to their wants, and their owner is gratified with a taste of the whole. Sweet mignonett cannot be ton highly recommended. This plant is easily cultivated by drills in the garden, and is one of the finest and richest flowers in the 
world from which the honey-bee can extract its food.

The Vermont hive is the only one I can use to much advantage or profit, and yet there are many improvements, which are far superior to the old bos. In the summer of 1834, I received in swarms and extra honey from my best stock thirty dollars, and from my poorest, fifteen dollars. My early swarms afforded extra honey which was sold, anounting to from five to ten dollars each live; and all my late swarms which were doubled, stored a sufficient quantity of food to supply them through the following winter.

The rules in the foregoing work, perhaps, may be deemed, in some instances, two particular; yet, in all cases, they will be found to be safe and unfailing in their application, liable to exceptions, such as are incident to all specific rules. 


. 







\section{LIBRARY OF CONGRESS

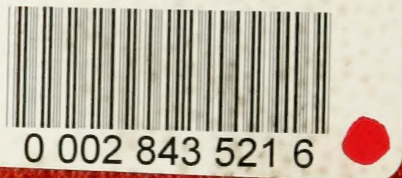

$-$

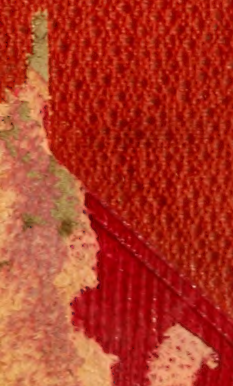

